\title{
Биохимическая оценка плодов перспективных форм жимолости алтайской (Lonicera altaica Pall.), интродуцированной в условиях ботанического сада г. Астаны
}

\section{Biochemical assessment of the fruits of promising forms of Altai honeysuckle (Lonicera altaica Pall.) in culture, for adaptation to the conditions of the botanical garden of Astana}

\author{
Вдовина Т. А., Лагус О. А. \\ Vdovina T. A., Lagus O. A. \\ Алтайскийботанический сад КН МОН РК, г.Риддер, Казахстан.E-mail: Altai_bs@таil.ru \\ Altai Botanical Garden Science Committee of the Ministry of Education and Science Republic of Kazakhstan, Ridder, Kazakhstan
}

Peферат. В статье приводятся результаты исследований биохимического состава плодов жимолости алтайской. Содержание витамина С и сахаров в ягодах невысокое, что характерно для этого вида. По содержанию фенольных веществ отмечен высокий диапазон варьирования. В накоплении общего сахара кислотности и сухих веществ вариабельность незначительна.

Ключевые слова. Биохимический состав, жимолость алтайская, плоды, сеянец, форма.

Summary. The article presents the results of research on the biochemical composition of the fruit of the Altai honeysuckle. The content of vitamin $\mathrm{C}$ and sugars in the berries is not high which is typical for this species. The content of phenolic substances showed a high range of variation. In the accumulation of total sugar acidity and dry matter variability is not significant.

Key words. Biochemical composition, form, fruits, Lonicera altaica Pall., seedling.

Жимолость относится к числу перспективных ягодных культур, так как ее плоды созревают на две недели раньше, чем у земляники. Растения имеют высокую зимостойкость как вегетативных, так и генеративных органов, ежегодно плодоносят. Богатый биохимический состав делает эту культуру перспективной для здорового питания. Ее плоды содержат комплекс витаминов, сахаров, кислот, пектиновых веществ, макро- и микроэлементов. Устойчивость к вредителям и болезням обеспечивает получение экологически чистой продукции.

В последние годы интерес к жимолости алтайской - Lonicera altaica Pall. - вызван тем, что ее ягоды не осыпаются, и она используются как исходный материал для гибридизации с целью получения сортов с прочным прикреплением ягод. С участием этого вида выведены сорта: 'Берель', 'Галочка', 'Огненный Опал' и несколько номерных гибридов, у которых плоды на кустах держатся в течение двух недель. К сожалению, все они унаследовали горчинку в плодах.

Материалом для интродукции в Алтайский ботанический сад послужила жимолость алтайская Lonicera altaica, собранная в окр. г. Риддер хр. Ивановский, Линейский, Кокса, в ур. Алешкин ключ, Палевая яма, рядом с посельем Босяково и Серый луг, по р. Разливанке. Коллекция жимолости алтайской - Lonicera altaica- в настоящее время представлена 22 формами, возрастное состояние которых более 30 лет, и сеянцами, возраст которых 5 лет.

Основной задачей при интродукции являлось изучение хозяйственно-биологических особенностей, а также выявление форм с максимальным биохимическим потенциалом для этого вида в условиях Западного Алтая. 
Методической основой проведения научно-исследовательской работы являлись «Программа и методика сортоизучения плодовых, ягодных и орехоплодных культур» (Седов, Огольцова, 1999), учебное пособие «Селекция и сортоведение плодовых и ягодных культур» под редакцией профессора А. С. Татаринцева (1981). Урожайность определяли методом полного съема плодов. Определение массы плодов проводили с точностью до 0,01 г, длину и ширину измеряли штангенциркулем с точность до 0,1 мм. Форму плодов и листовой пластинки устанавливали по индексу $1 / \mathrm{d}$ соотношение длины к ширине. Оценка вкуса плодов жимолости проводилась органолептическим методом по шестибалльной шкале вкусовых вариаций, которая основана на степени горечи в плодах (в баллах): сладкие, кисло-сладкие и пресные без горечи (0 баллов); кисловато-сладкие с незначительной горчинкой (1 балл); слабо-горькие (2 балла); кисло-горькие (3 балла); горькие (4 балла); хинно-горькие (5 баллов).

Биохимический анализ ягод жимолости (содержание сахаров, витамина $\mathrm{C}$, сухих веществ, фенольных веществ и титруемая кислотность) выполнены ТОО «Казахский научно-исследовательский институт перерабатывающей и пищевой промышленности».

В условиях интродукции проведено изучение основных хозяйственных и биологических признаков. Растения жимолости алтайской - это прямостоячие сильнорослые кустарники от 1,2 м до 2,4 м. Кора одревесневших побегов и стволиков серовато-бурая, отслаивающаяся продольными полосками. Форма листьев у жимолости алтайской достаточно изменчива даже на одном растении. Так, в базальных узлах побега лист более округлый, чем в середине; он более вытянут в терминальных узлах побега. Индивидуальная изменчивость проявляется в вариациях по форме основания и вершины листа. Основание листа бывает округлым, клиновидным или заостренным. По соотношению длины и ширины листа представлены следующие формы: округло-эллиптическая; широкоэллиптическая; продолговато-эллиптическая; удлиненно-эллиптическая; ланцетовидная. Листовые пластинки средней величины, 3,8-6,5 см длины, 1,3-2,0 см ширины, на коротких черешках.

К достоинствам жимолости алтайской в нашем регионе следует отнести высокую зимостойкость растений. Она служит критерием в оценке адаптации этой культуры к условиям выращивания. Многолетними наблюдениями установлено, что сортообразцы жимолости алтайской перезимовывают без существенных повреждений почек и однолетних побегов даже в суровые зимы. Так, на протяжении 14 лет (2004-2018 гг.) отмечалось понижение температуры в декабре, январе до -38-42 ${ }^{\circ} \mathrm{C}$. Высокую адаптивность к действию низкотемпературных стрессов в весенний период проявляет и генеративная сфера растений жимолости алтайской, что обеспечивает ежегодное плодоношение.

Проведение фенологических наблюдений показывает, что жимолость начинает вегетацию одной из первых ягодных культур, во второй декаде апреля, при переходе средней суточной температуры через $0{ }^{\circ} \mathrm{C}$. При раскрывании почек первыми появляются бутоны и одновременно с ними зачатки листьев. Цветение обычно наступает через 10-16 дней после массового развертывания листьев, в первой и второй декадах мая. Первыми зацветают бутоны верхнего яруса, затем нижнего. Период цветения составляет 8-12 дней. Полное созревание плодов жимолости алтайской наступает в конце июня, на 17-20 дней позже, чем у сортовой. Сдвиг этой фенофазы в отдельные годы достигает 5-7 дней в зависимости от климатических условий. Годичный прирост побегов составляет 6-16 см.

Урожайность у большинства форм составляет 1,2-2,4 кг/куст. Созревание плодов не одновременное, но, учитывая, что они не осыпаются в течение двух-трех недель из-за прочности прикрепления, их сбор можно проводить в один прием, без потерь.

Форма и размеры плодов в пределах одного куста постоянны, но значительно варьируют у разных особей. Размеры плодов жимолости алтайской по длине от 9,8 мм у формы № 21 до 19,8 мм у формы № 22, диаметру от 5,7 мм у формы № 17 до 9,7 мм у формы № 4. (рис.). По массе плодов вариации от 0,24 у формы № 1 до 0,60 г у формы № 20. Масса крупного плода в два раза превосходит массу мелкого. Довольно крупные плоды, от 0,56 до 0,66 г, имеют формы под номерами 4, 13, 18, 20, 22. По этому признаку жимолость алтайская уступает жимолости камчатской.

Вкус плодов у особей жимолости алтайской изменчив, он определяется количественным содержанием сахаров, кислот и горьких веществ, среди которых бутиловые эфиры яблочной и лимонной кислот. Нами отобраны сладкие, кисло-сладкие, слабо-горькие и кисловато-горьковатые образцы.

Исследования биохимического состава плодов жимолости алтайской проведены на содержание витамина С, общих сахаров, растворимых сухих веществ, фенольных веществ, кислотности, что 

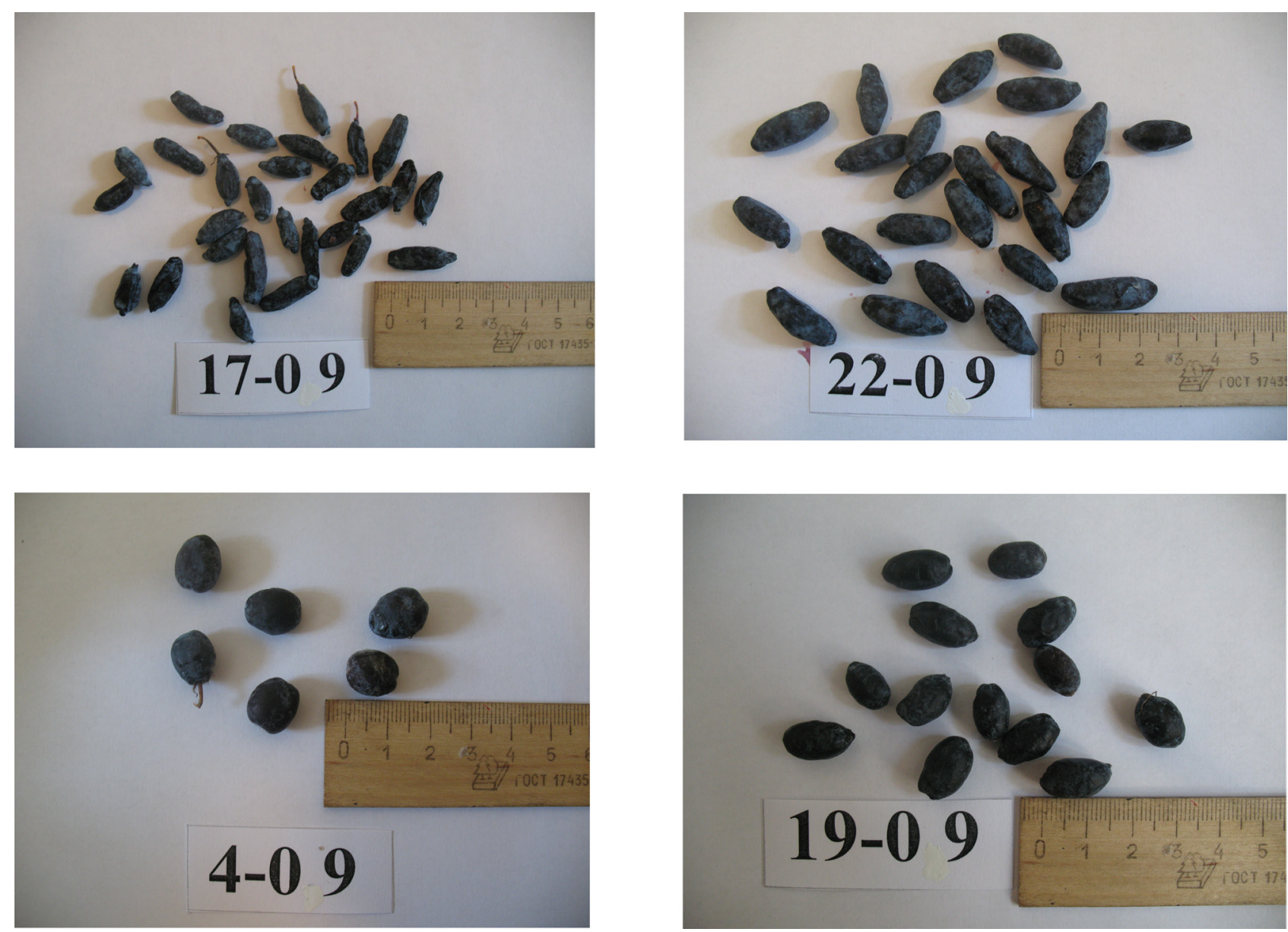

Рис. Разнообразие плодов жимолости алтайской по форме и размерам.

позволило получить комплексную оценку. Жимолость не относится к С-витаминным культурам, но лечебное действие аскорбиновой кислоты усиливается благодаря синергизму с Р-активными веществами. Витамин С оказывает влияние на самые разнообразные функции организма. Он стимулирует деятельность желез внутренней секреции, кроветворение, способствует нормальному развитию организма, повышает его адаптационные способности, сопротивляемость к неблагоприятным воздействиям внешней среды (инфекции, интоксикации, перегреванию, охлаждению и др.) (Бочарова, 2013). Как показывают данные проведенных исследований, содержание витамина С в плодах жимолости варьирует в пределах от 38,14 мг/\% у формы № 22 до 54,8 мг/\% у формы № 18 (Табл.). Наибольшее накопление витамина С выше 45 мг/\% отмечено у следующих номеров: № $18-54,80$ мг/\%, № 17 - 53,12 мг/\%, № $19-45,58$ мг/\%. Содержание витамина С в ягодах жимолости алтайской не высокое и зависит, прежде всего, от формы.

Таблица

Биохимические показатели плодов жимолости алтайской

\begin{tabular}{|c|c|c|c|c|c|}
\hline Форма & $\begin{array}{c}\text { Витамин } \\
\text { С, мг/\% }\end{array}$ & $\begin{array}{c}\text { Общий } \\
\text { сахар, \% }\end{array}$ & $\begin{array}{c}\text { Титруемая } \\
\text { кислотность, \% }\end{array}$ & $\begin{array}{c}\text { Растворимые сухие } \\
\text { вещества, \% }\end{array}$ & $\begin{array}{c}\text { Фенольные } \\
\text { вещества, мг/100г }\end{array}$ \\
\hline № 17 & 53,12 & 0,85 & 2,46 & 11,6 & 750 \\
\hline № 18 & 54,80 & 0,94 & 2,42 & 12,8 & 780 \\
\hline № 19 & 45,58 & 0,72 & 3,20 & 15,8 & 820 \\
\hline № 21 & 40,18 & 0,70 & 3,61 & 9,8 & 705 \\
\hline № 22 & 38,14 & 0,78 & 3,31 & 10,0 & 790 \\
\hline № 23 & 35,52 & 0,81 & 3,49 & 11,6 & 790 \\
\hline
\end{tabular}


Растворимые сахара являются наиболее активными участниками метаболических процессов в человеческом организме. Содержание сахаров у всех форм низкое, что характерно для вида жимолость алтайская - Lonicera altaica. Оно намного ниже, чем у сортовой жимолости. У форм № 17, № 18, № 23 его содержание более 0,81 \%, у других (№ 19, № 22, № 21) несколько ниже 0,70-0,78 \%. У форм под номерами 17 и 18 наблюдается повышенное содержание витамина С и общего сахара в сравнении с другими формами.

На органолептические свойства плодов большое влияние оказывает сахарокислотный индекс. Вкус плодов жимолости определяется не только малым содержанием сахаров, но и пониженной кислотностью, как у форм под номерами 17 и 18 (0,85 \% и 2,46 \%, соответственно; 0,94 \% и 2,42 \%, соответственно). В ягодах жимолости содержится от $2,42 \%$ до 3,61 \% органических кислот - щавелевой, винной, которые придают плодам оригинальный кисловатый вкус. Кислоты играют определенную роль в поддержании кислотно-щелочного равновесия в организме человека.

Одним из важнейших показателей качества плодов является содержание сухих веществ. Оно в плодах анализируемых форм колеблется в пределах 9,8-15,8 \%. Повышенное содержание, более 12,0 \%, характерно для двух форм: № $18-12,8$ \%, № $19-15,8$ \%. Содержание растворимых сухих веществ отмечено на уровне, присущем для сортов.

По содержанию биофлавоноидов жимолость алтайская занимает ведущее место среди плодовых и ягодных культур. Высокая антиоксидантная активность плодов жимолости находится в прямой зависимости от содержания фенольных соединений. В результате взаимного влияния и естественного сочетания, различных биофлавоноидов с сахарами и органическими кислотами формируются оттенки вкуса. Преобладание тех или иных из них обуславливает определенную пищевую ценность плодов. Отличительной особенностью исследованных образцов явилось довольно высокое содержание фенольных веществ от 750 мг/\% у формы № 17 до 820 мг/\% у формы № 19, что в два раза выше, чем у сортов. Большой интерес по содержанию фенольных веществ представляют формы № 18 фенольные вещества - 780 мг/кг, № 19 - 820 мг/кг, № 21 - 805 мг/кг, № 23 - 790 мг/кг. Такая вариабельность показывает, что накопление этого вещества в ягодах жимолости алтайской зависит от генотипа особи.

Наиболее ценными для возделывания и дальнейшей селекционной работы являются три формы под номерами 17, 18, 19 и сеянец 1-2014, обладающие несколькими полезными свойствами: урожайностью, крупноплодностью, неосыпаемостью плодов и высоким содержанием биохимических веществ. Их характеристика приводится ниже.

Форма № 17. Куст высокий, 1,9 м. Зимостойкость высокая. Масса плода- 0,56 г. Форма плодов веретеновидная, длина 15,9 $\pm 0,81$ мм, диаметр 7,7 \pm 0,35 мм. Вкус плодов кисло-сладкий, с горечью. Срок созревания - поздний. Урожайность- 2,0 кг/куст. Плоды отличаются высоким содержанием витамина С $(53,1$ мг/\%) и фенольных веществ $(750$ мг/кг).

Форма № 18. Куст высокий, 2,1 м. Плоды бочонковидные, длиной 13,5 $\pm 0,42$ мм, диаметром $9,0 \pm 0,44$ мм. Масса плодов- 0,66 г. Срок созревания плодов - поздний. Вкус кисловато-горьковатый, с ароматом. Форма характеризуется высокой зимостойкостью. Урожайность $-2,4$ кг/куст. Плоды накапливают витамина С (54,80 мг/ \%), фенольных веществ (780 мг/кг), сухих веществ $12,8 \%$.

Форма № 19. Куст высокий 2,4 м. Плоды бочонковидные, длиной $12,2 \pm 0,59$ мм, диаметром $7,5 \pm 0,28$ мм, массой - 0,46 г. Кожица плотная, вкус горьковатый, с ароматом. Срок созревания плодовпоздний. Форма характеризуется высокой зимостойкостью. Урожайность $-1,8$ кг/куст. Эта форма является лидером по содержанию фенольных веществ (820 мг/кг) и сухих веществ (15,8 \%).

Сеянец 2-2014. Куст высотой, 1,0 м, компактный. Этот сеянец отличается скороплодностью, первое плодоношение отмечено на четвертый год в 2018 г. Форма плодов бочонковидная, длина 21,0 \pm 0,42 мм, диаметр 14,5 \pm 0,23 мм. Плоды очень крупные 1,0 г, вкус кисло-сладкий, с горечью. Зимостойкость высокая.

Жимолость алтайская в условиях культуры вполне адаптирована. Успех интродукции заключается в сохранении биологических особенностей этого вида, а также в длительности культивирования имеющихся форм, возрастное состояние которых более 35 лет. На основании полученных данных по комплексной оценке биохимических показателей плодов жимолости алтайской выделяются формы: № 18 - по всем параметрам, № 17 и № 19 - по трем, № 23 - по двум и № 21 - по одному. Они представляют интерес для дальнейшей интродукции и гибридизации. 


\section{ЛИТЕРАТУРА}

Бочарова T. $\boldsymbol{E}$. Биохимическая оценка качества перспективных сортообразцов жимолости селекции ГНУ ВНИИС им. И. В. Мичурина // Достижения и перспективы развития культуры жимолости в современных условиях: материалы II Междунар. науч.-методологич. дистанционной конф. (23 марта - 23 апреля 2013 г., Мичуринск-наукоград РФ). - Воронеж: Кварта, 2013. - С. 17-22.

Седов Е. Н., Огольцова T. П. Программа и методика сортоизучения плодовых, ягодных и орехоплодных культур. - Орел, 1999. - 608 с.

Tатаринцева $\boldsymbol{A}$. $\boldsymbol{C}$. Селекция и сортоведение плодовых и ягодных культур. - М.: «Колос», 1981. - 367 с. 